haps, by the growth of micro-organisms. It would be out of place, however, to develop these views here.

The chapters on the analysis of margarine, etc., contain little to comment upon, except that enough stress is not laid on the iodine value and the hexabromide tests. In the portions dealing with nutritional chemistry the author gives a welcome review of the work done and of the opinions held by medico-chemists on the so-called "vitamines," "food hormones," "accessory food factors," "sitacoids," and "advitants.". These are "substances" which are supposed to be present in, and give digestibility to, natural fats, and to be absent in prepared or artificial fats. The medico-chemist has thus named them. As Goethe says :-

Denn eben, wo Begriffe fehlen

Da stellt ein Wort zur rechten Zeit sich ein.

Blessed words! Not one of these so-called substances has been isolated, and no one knows their chemical formulæ or characters. Why a "substance" and not a "condition" of a known substance-say, a peroxidised form of some fat? Mr. Clayton seems to see this, and that the whole matter needs consideration from the chemical rather than from the medical point of view, for he states that the term "vitamine" is wrong, as no nitrogen has ever been detected in any of these alleged substances.

The book contains thirty-five pages of bibliography, and a patents index, and should prove of great assistance to food and emulsion chemists.

\section{HARRY INGLE.}

\section{Our Bookshelf.}

Le Parc National Suisse. Par S. Brunies. Traduit par Samuel Aubert. Pp. 274. (Bâle: Benno Schwabe et Cie, 1920.) Price 12 francs.

The map of the Swiss Topographic Survey, on the scale of $\mathrm{I}: 5^{\circ}, 000$, forms part of this attractive publication. The reserve, established by the Federal Government in 1913 , occupies a mountainous district trenched by two tributaries of the Inn. The best approach is by Zernez in the Lower Engadine, and the carriage-road to the Münstertal passes across the park. The author's description, translated from the original German, is picturesque and vivid; but the features that appeal to the visitor trained in scientific pursuits are always kept in view. Special chapters deal with geology and natural history, and the studious revival of the local Latin dialect is recognised by the stress laid on "romand" names. Pronunciations and a list are considerately furnished, and the careful translator informs us that the pronunciations given are those used in at least one village-that of Sinuos-chel. Great praise No. 2667 , voL. I06] must be given to the illustrations. Apart from the four exquisite photogravures of the scenery of the park, Mr. H. Pfendsack of Pontarlier has supplied vigorous line-drawings of animals and plants, in every case connecting the subject with its stern environment. Compare, for instance, his Pinus montana (p. 149), recumbent but undefeated, clutching at the rock, with the climbing birds enjoying themselves as alpinistes on p. 217. He represents with equal insight the family life of the ibex, which it is proposed to restore to its former haunts, and the prolific poppy growing from a heap of stones. The author has well represented the history of the Alpine overfolds by successive sections. It is a pleasure to possess his book.

G. A. J. C.

(I) Easy Lessons in Einstein: A Discussion of the More Intelligible Features of the Theory of Relativity. By Dr. Edwin E. Slosson. With an article by Albert Einstein and a bibliography. Pp. vii + 128. (London: George Routledge ani Sons, Ltd.; New York: Harcourt, Brace, and Howe, 1920.) Price $5 s$. net.

(2) From Nerwton to Einstein: Changing Conceptions of the Universe. By Dr. Benjamin Harrow. Pp. 95. (London: Constable and Co., Ltd., I920.) Price $2 s .6 d$.

(3) Die Einsteinsche Relativitätstheorie. By Prof. U. Kopff. Pp. 24. (Leipzig: Greszner und Schramm, 1920.) Price $\mathrm{x} .50$ marks.

(I) Dr. Slosson gives us in his book a breezy account of what he calls the more intelligible features of the theory of relativity with popular illustrations of distorting mirrors, references to Mr. H. G. Wells's "Time Machine" and other scientific romances, diagrams purporting to portray a four-dimensional cube, and general goodhumour-a book with which the absolute layman may amuse himself for a few hours.

(2) Dr. Barrow gives a more serious, but equallv readable, summary of the development of physical science from the mechanical period of the eighteenth century through the electrical theories of the nineteenth to the present day. Here also the layman will find profitable reading.

(3) The little pamphlet by Prof. Kopff is a reprint of a lecture on the relativity theory to the Natur-historisch-Medizinischen Verein at Heidelberg in June, r920.

Technical Handbook of Oils, Fats, and Waxes. By P. J. Fryer and F. E. Weston. Vol. i., Chemical and General. Third edition. (The Cambridge Technical Series.) Pp. xii $+280+$ xxxvi plates. (Cambridge: At the University Press, 1920.) Price I5s. net.

THE changes occurring in the industrial situation have caused the authors to add a certain amount of matter, and to make a number of alterations in the text of the first edition, which was reviewed in Nature of January I7, I918. Another addition has been made in the form of analytical data inserted in the text, and a number of footnotes, chiefly giving references to original papers, are now included. 